\title{
An empirical examination of the contents and evolution of the composing factors of logistics enterprise competitiveness: a perspective from China
}

Weihua Liu, Binglian Liu, Ou Tang, Lujie Chen and Xiaoyan Liu

\author{
Linköping University Post Print
}

\section{Tweet}

N.B.: When citing this work, cite the original article.

This is an electronic version of an article published in:

Weihua Liu, Binglian Liu, Ou Tang, Lujie Chen and Xiaoyan Liu, An empirical examination of the contents and evolution of the composing factors of logistics enterprise competitiveness: a perspective from China, 2014, International Journal of Logistics, (17), 6, 459-484.

International Journal of Logistics is available online at informaworld ${ }^{\mathrm{TM}}$ :

http://dx.doi.org/10.1080/13675567.2014.913555

Copyright: Taylor \& Francis (Routledge) http://www.routledge.com/

Postprint available at: Linköping University Electronic Press http://urn.kb.se/resolve?urn=urn:nbn:se:liu:diva-113752 


\title{
An Empirical Examination of the Contents and Evolution of the \\ Composing Factors of Logistics Enterprise Competitiveness: A \\ Perspective from China
}

\begin{abstract}
Managers and researchers are increasingly interested in the factor that logistics enterprise competitiveness (LEC) has significant effects on the development of Chinese logistics enterprises, especially in view of the enterprise life cycle. This paper investigates the contents and evolution of the composing factors of LEC in China by survey. With Statistical Product and Service Solutions (SPSS 15.0) software, the factor analysis method is used to determine the effects of each factor on LEC. Furthermore, the comparative analysis method is applied to compare the composing factors of LEC in different types of logistics enterprises and at different enterprise life cycle stages. The results show that factors of LEC according to their descending importance level are corporate capabilities, corporate resources, and dynamic mechanism. Three kinds of corporate capabilities (financial management capability, logistics risk control capability, and human resource management capability) and two kinds of corporate resources (corporate human resources and corporate culture) have the greatest influence on the development of LEC, but in reality have poor practical performance, and hence deserve more consideration from the enterprises.
\end{abstract}

Key words : Logistics enterprises competitiveness; composing factors; evolution process; empirical research.

\section{Introduction}

In recent years, logistics management and services have greatly improved through the effort of Chinese logistics enterprises scale, network, and brand. These enterprises play a significant role in accelerating the development of the Chinese logistics industry. According to the Top 50 Chinese Logistics Enterprises list released by the China Federation of Logistics and Purchasing, the minimal annual revenue needed to be included in this list increased from RMB 360 million in 2005 to RMB 1.22 billion in 2010. COSCO Logistics Company reached 104.6 billion RMB in annual revenue as the top ranked company in 2010 . The data obviously indicates the rising trend of competitiveness of logistics companies in China. As suggested by Liu et al (2010), a firm's success or competitiveness cannot be attributed to only one factor, Therefore, an empirical examination of the contents of composing factors and the evolution of logistics enterprise competitiveness (LEC) is conducted in this paper, to help managers understand which composing factors of LEC significantly affect the development of Chinese logistics enterprises.

Competitiveness is a type of capability and its potential has to be realized in a firm's daily operations. Through competitiveness, an enterprise can obtain a competitive advantage (Snyder and William, 1992). Logistics enterprise competitiveness or the competitiveness of a logistics service provider (LSP) refers to a firm's capacity to compete in a logistics service market, increase 
its market share, and achieve sustainable growth and profitability (Liu et al., 2010; Liu, 2011). With the rapid development of logistics enterprises in China during the last two decades and the increase of external environmental pressure, many logistics enterprises continuously seek new ways of achieving superior performance to differentiate themselves from competitors and safeguard their competitive positions. Thereby, scholars and managers are increasingly curious about LEC studies (Liu, 2011).

In this paper, we aim to not only fill the gaps in the current theoretical research of LEC, but also solve the critical management problems of LEC faced by Chinese logistics enterprises today. Given the existing research, literature review and the survey method are most often used to study LEC (Harding, 1998; Chapman et al., 2003; Gunasekaran and Ngai, 2003, 2004; Pannayides and So, 2005; Lai, 2004; Wang et al., 2006; Yeung et al., 2006; Liu et al., 2010; Liu, 2011; Liu et al., 2013). Most of the studies focus on the definition and composing factors of LEC, the evaluation of LEC, and the cultivation of LEC. However, the literature review in Section 2 indicates that there are still gaps existing in current theoretical research. First, the research exploring LEC in the view of dynamic competitiveness, especially from the perspective of the enterprise development life cycle, is insufficient. Second, many papers summarize logistics enterprises only as one type of logistics service provider, and the difference in logistics enterprises business scope is ignored. The LEC factors of different types of logistics enterprises also may not be the same. Third, there are a large number of empirical studies focusing on the composition of LEC (Liu et al., 2010; Liu, 2011; Liu et al., 2013), but the various types of LEC factors needed in different enterprise development stage are not stated clearly. The evolution of composing factors of LEC for different types of logistics enterprises is also not presented.

From a practical perspective, we also attempt to do further research based on the current situation of Chinese LEC. The following important practical problems faced by Chinese logistics enterprises will be discussed in detail: (1) for managers of China logistics enterprises, which factors are more important and which need immediate improvement to better maintain and improve LEC; (2) from the perspective of the enterprise life cycle, is there a difference in composing factors of LEC for Chinese logistics enterprises in different development stages, and how can managers of logistics enterprise identify and manage these differences; and (3). the composing factors of LEC for different types of logistics enterprises might have similarities and differences, so how to understand and manage these similarities and differences?

In this research, the types of Chinese logistics enterprises are divided according to different business scopes. Four kinds of logistics enterprises are discussed in this paper (see Section 3). They are platform logistics company (PLLC), universal logistics company (ULC), professional logistics company (PRLC), and the supply chain management company (SCMC). A survey was conducted with 220 questionnaires received. Some interesting results are found based on the comprehensive analysis of the received questionnaires. The managerial significance of this study is enormous as it helps managers determine which LEC factors have a significant effect on the development of Chinese logistics enterprises in view of the enterprise life cycle.

This paper is organized as followings. After this short introduction, an overview of relating 
literature is presented in section 2. The four types and life cycle stages of Chinese logistics enterprises are defined in Section 3. Section 4 illustrates the composing factors and three-dimension analysis framework of LEC. A survey about LEC and the profile of the respondents are presented in Section 5. Following that, the influence of the composing factors on LEC is discussed in Section 6. A comparison of LEC composing factors among the different types of companies and enterprise life cycle stages is indicated in Section 7. Finally, Main conclusions and management insights are presented.

\section{Literature Review}

The concept of firm-level competitiveness is related to competitive advantage (Porter, 1985; Ghemawat, 1986). Competitive advantage refers to the position of superiority within an industry that a firm has developed in comparison to its competitors. Enterprise competitiveness is a comprehensive capability that ensures the enterprise performs well in customer service, annual revenue, and long-term development (Wang and Ahmed, 2007; Wang, 2010). In recent years, LEC has received increasing consideration in literature. Most of the studies focus on the definition and composing factors of LEC, the evaluation of LEC, and the cultivation of LEC.

\subsection{Definition and composing factors of LEC}

Defining the competitiveness of a logistics company clearly is important because it affects the reliability and rationality of the research. Traditionally, the competitiveness of a firm refers to the firm's strategies, process capabilities, and resources (Wong and Karia, 2010). A theory of the core competitiveness of enterprises shows that competitiveness should be valuable, hard to imitate, and ingenious (Prahlad and Hamel, 1990). The concept of LEC is derived from enterprise competitiveness and has some unique characteristics. According to Liu et al (2010) and Liu (2011), LEC or the competitiveness of a logistics service provider refers to a firm's capacity to compete in a logistics service market, increase its market share, and achieve sustainable growth and profitability.

Scholars have studied the composing factors of LEC based on different aspects. The resource-based view believes that the unique resource is the source of enterprise competitiveness (Barney, 1991). Some logistics literature suggests that there are direct or indirect relationships between various resources and performance or competitive advantages of the logistics enterprise (Lai et al., 2008; Wong and Karia, 2010; Sandberg, 2011). A study on resource theory demonstrates that technological readiness and complementarities are two important capabilities that allow logistics enterprises to improve competitiveness (Richey and Daugherty, 2007).

LEC is a comprehensive capability system. The factors influencing LEC are not only resources but other factors as well (Cantwell, 2005). Panayides and So (2005) believe that some factors, including quality, delivery, service and flexibility, are the key to the success of logistics service enterprises. Liu and Lyons (2011) pointed out that service capability is a critical factor that helps third-party logistics (3PL) providers gain superior financial performance and competitiveness. Cetindama and Kilitcioglu (2013) believe that firm-level competitiveness is based on three key pillars: competitive outcome/performance (output), firm resources (input), and the managerial 
processes and capabilities, in which the firm resources are utilized and flourished. Liu et al. (2010) conducted a detailed empirical study on LEC and presented 13 firm-specific capabilities that contribute to LEC. The 13 firm-specific capabilities are: strategic management; operations management; service quality; information technology (IT); service network; customer relationship management (CRM); innovation; marketing; inventory management; human resource management (HRM); corporate culture; business process management (BPM); and cost management.

These opinions about the composing factors of LEC mentioned above are valuable for exploring LEC further. Hence, in this paper, the factors of resources and capabilities are included in the design questionnaire of LEC.

\subsection{Evaluation of LEC}

Many scholars have conducted research on the logistics competitiveness evaluation index system based on the analysis of composing factors of LEC. For example, Houston (1992) explored the validity of the competitiveness index by investigating both internal and external validity of the measure. A quantitative model was built to identify the life cycle stage of core competence of the logistics enterprise based on the composing factors of LEC (Han and Huang, 2008). A professional logistics evaluation model was designed for coal port logistics (Xiao and Chen, 2008). The performance of a logistics company was evaluated from the aspects of innovation, customer response, and flexible operation capability ( $\mathrm{Lu}$ and Yang, 2010). According to the cluster analysis model, better customer response and innovation capabilities result in better company performance.

In general, traditional evaluation of LEC adopts such approaches as analytic hierarchy process (AHP), multidimensional and comprehensive evaluation model, structural equation model (SEM), factor analysis, and empirical analysis. For example, a SEM-based analysis conducted by Tan et al. (2007) focused on the importance of operations and flexibility in logistics capabilities. Yeo et al. (2008) adopted the factor analysis method to evaluate the competitiveness of container ports in Korea and China. A case study was carried out to assess the role of flexibility in satisfying competitive opportunities in consideration of supply chain uncertainties (Mohamed et al., 2010).

The combined method has also been used to evaluate the competitiveness of logistics enterprise (Li, 2008). For instance, Shao et al. (2008) introduced a hybrid index evaluation method based on the AHP and fuzzy principles. In a port logistics competitiveness evaluation (Fan, 2009), the fuzzy theory and AHP method were employed. A comprehensive evaluation model has been built by integrating threshold and importance analysis, matrix analysis, and fuzzy multi-criteria decision making. (Ding, 2009).

Recently, some new methods such as real-valued genetic algorithm and niche method have also been applied. For instance, Zhang et al. (2010) used niche method to evaluate the competitiveness of logistics enterprises. Analysis diagnosis models are established by integrating a real-valued genetic algorithm to objectively forecast and evaluate LEC (Ding et al., 2013).

Although differences exist in the evaluation index systems or models, the perspectives from which 
LEC is evaluated are similar, including capabilities in organization, capabilities in innovation, strategy position, operation flexibility, and customer responsiveness, etc. Most of the previous studies only make an evaluation for static LEC rather than dynamic LEC, and the evolution characteristics of LEC are not considered in the evaluation.

\subsection{Cultivation and development of LEC}

Evolutionary theory of business activity indicates that environment will affect the capability development and evolution that lead to competitiveness stability (Fortune and Mitchell, 2012). As an important research branch of LEC, the cultivation of LEC has been discussed in many studies. The mainstream view of the cultivation and development of LEC includes continuous learning, implementation of technical innovation, capability exploitation, and upgrading and adapting to the international culture, etc. For example, a good study system can contribute to the cultivation of LEC (Esper and Fugate, 2007). Sandberg (2011) elaborated the effects of dynamic capabilities on the sustainable competitive advantage. His study revealed that an IT system could enhance the development of LEC. Liu and Hsu (2011) proposed a perspective of dynamic capabilities, which suggested that the successful growth of a firm hinges on a strategic management logic of capability-based growth, including both capability exploitation and capability upgrading. Liu et al. (2012) discussed the development of LEC from the perspective of the enterprise life cycle, but they did not name the factors that are most important for Chinese logistics enterprises and which factors need to immediate improvement. Liu et al. (2013) has studied the development path and key capabilities of two different types of logistics enterprises, and an empirical examination on the Transfer Road Port Logistics and Guangzhou P.G. Logistics Group in China has been conducted. As culture is an important aspect to the cultivation of LEC, Canen and Canen (2004) believe that the cultivation and development of LEC should be adjusted to the local cultural environment, especially for multinational logistics enterprises.

According to the literature review, LEC has received increasing considerations in recent years; however, there are still some gaps in the current research. For example, the analysis of the composing factors of LEC shows a lack of comprehensiveness; at least, the discussion from a dynamic perspective is insufficient. Some important issues need to be solved. For instance, from the view of the enterprise life cycle, is there any difference in the composing factors of LEC when the logistics enterprise is in different life cycle stage? For different types of logistics enterprises, are the composing factors of LEC different? If so, what are the differences? Inspired by the gaps in the current research of LEC as well as the critical management problems faced by logistics enterprises of China today, we conducted an empirical study based on the survey method to analyze the composing factors of LEC of China. In this paper, the evolution of composing factors of LEC for different life cycle stages is presented.

\section{Types and life cycle stages of Chinese logistics enterprises}

\subsection{Four types of logistics enterprises in China}

The scientific classification of logistics enterprises is the premise of this study, since the differences of service capabilities lead them to compete in different market segments (Lai, 2004). Some scholars cluster logistics service providers (LSPs) based on service capabilities (Lai, 2004) 
and strategic positioning (Yeung et al., 2006). The asset-based and non-asset-based LSPs are perhaps the most popular classification approaches of LSPs in terms of resources (Larson and Gammelgaard, 2001). This study theorizes that LSPs can be divided into different groups regarding different business scopes. Hence, logistics companies can be divided into four types: platform, universal, professional, and supply chain management, from the view of customer type and service scope (He and Liu, 2011). Table 1 shows the classification of different logistics enterprises. This research will analyze the composing factors and the evolution of LEC based on these four types of logistics enterprises.

Table 1. Classification of China logistics enterprises

\begin{tabular}{|c|c|c|}
\hline $\begin{array}{c}\text { Enterprises } \\
\text { type }\end{array}$ & Services scopes & Examples \\
\hline $\begin{array}{c}\text { Platform } \\
\text { logistics } \\
\text { company } \\
\text { (PLLC) }\end{array}$ & $\begin{array}{l}\text { The platform logistics company provides platform } \\
\text { services, including logistics supply/demand } \\
\text { information trade services, various transport } \\
\text { services, enterprise office renting and } \\
\text { management services, etc., to many small and } \\
\text { medium-sized logistics enterprises. The platform } \\
\text { logistics company includes port enterprises, } \\
\text { railway stations, highway freight stations, air } \\
\text { cargo stations, distribution centers, logistics } \\
\text { centers and parks, etc. }\end{array}$ & $\begin{array}{c}\text { Zhejiang Transfer Logistics } \\
\text { Co., Ltd.; } \\
\text { Shandong Gaijiagou Logistics } \\
\text { Co., Ltd. }\end{array}$ \\
\hline $\begin{array}{l}\text { Universal } \\
\text { logistics } \\
\text { company } \\
\text { (ULC) }\end{array}$ & $\begin{array}{l}\text { This type of logistics company includes transport } \\
\text { companies, warehousing companies, etc. They } \\
\text { provide a universal service that could be provided } \\
\text { by many companies. }\end{array}$ & $\begin{array}{l}\text { Guangzhou P.G. Logistics } \\
\text { Group Co., Ltd.; } \\
\text { Tianjin Baoyun Logistics Co., } \\
\text { Ltd. }\end{array}$ \\
\hline $\begin{array}{l}\text { Professional } \\
\text { logistics } \\
\text { company } \\
\text { (PRLC) }\end{array}$ & $\begin{array}{c}\text { This type of logistics company focuses on } \\
\text { personalized and professional services suitable to } \\
\text { a logistics company concentrating on a certain } \\
\text { industry, such as automotive, medical, appliance, } \\
\text { etc. }\end{array}$ & $\begin{array}{l}\text { Hebei Kailuan International } \\
\text { Logistics Co., Ltd.; } \\
\text { Shandong Rongqing } \\
\text { Cold-Chain Logistics Co., } \\
\text { Ltd. } \\
\end{array}$ \\
\hline $\begin{array}{l}\text { Supply } \\
\text { chain } \\
\text { management } \\
\text { company } \\
\text { (SCMC) }\end{array}$ & $\begin{array}{l}\text { This type of logistics company is an integrated } \\
\text { company that could provide integrated services, } \\
\text { such as offering a scheme for integrating and } \\
\text { optimizing the flow of logistics, information, and } \\
\text { capital in a supply chain. The most typical } \\
\text { company of this kind is Hong Kong Li \& Fung } \\
\text { Group. }\end{array}$ & $\begin{array}{l}\text { Shenzhen Eternal Asia Supply } \\
\text { Chain Management Ltd.; } \\
\text { Hong Kong Li \& Fung Supply } \\
\text { Chain Management Co., } \\
\text { Ltd. }\end{array}$ \\
\hline
\end{tabular}

\subsection{The development stages of logistics enterprises}

Life cycle phenomena exist in the course of every enterprise development. Based on the general classification (Haire, 1959; Leontiades, 1980; Cameron and Whetten, 1981), the entire life cycle of a logistics enterprise can be divided into the initial stage growth stage, maturity stage, and 
regeneration stage. In different stages, the logistics enterprise is faced with different opportunities, challenges, and environments. There are also differences in composing factors of LEC at different stages. In this paper, the discussion about the evolution process for the composing factors of LEC is based on the premise of four life cycle stages.

\section{Composing factors and three-dimension analysis framework of}

\section{LEC}

\subsection{Composing factors of LEC}

Corporate resources and capabilities are discussed the most as the composing factors of LEC in the literature review. In general, firm resources or corporate resources are referred to as physical, financial, individual and organizational capital attributes for a firm (Liu et al., 2010). In contrast with resources, corporate capabilities are emphasized as being more likely to be the most important source of competitive advantage, since they are hard to replicate (Liu et al., 2010). Collis and Montgomery (1995) pointed out that capabilities are the most likely source of sustainable competitive advantage.

The resource-based view (RBV) contends that resources of firms are the key factors of sustained competitive advantage (Shang and Marlow, 2005). Some early logistics studies suggested that logistics performance can be explained by a firm's resources including physical resources, technology resources, and managerial competences (e.g. Chiu, 1995; Larson and Kulchitsky, 1999; Alshawi, 2001; Mentzer et al., 2004; Beinstock et al., 2008). Results of Wong and Karia (2010) show that all LSPs acquire physical, human, information, knowledge and relational resources and then bindle them together in various specific manners to create inimitable and firm-specific capabilities. The research of Liu et al. (2010) is the most widely cited paper about LEC, and 13 types of capabilities influencing LEC are proposed in her research. The first 12 capabilities, including strategic management; operations management; service quality; IT; service network; CRM; innovation; marketing; inventory management; HRM; corporate culture; and business process management, have already been discussed before Liu et al. (2010) in research of factors contributing to LSP success (Harding, 1998; Chapman et al., 2003; Gunasekaran and Ngai, 2003, 2004; Lai, 2004; Pannayides and So, 2005; Wang et al., 2006; Yeung et al., 2006). The 13th capability, cost management, which is the accounting and control of logistics costs, has been identified as vital to companies seeking and improving competitive advantages (Liu et al., 2010). Apart from these resources and capabilities mentioned above, other primary resources are the entrepreneur's philosophy (Gorynia, 2004), entrepreneur's capability (Gorynia, 2004; Kor and Mesko, 2013) and networking capability (Mu, 2013).

The composing factors of LEC are not only resources and capabilities, but other factors as well (Cantwell, 2005). Matching mechanisms are the mechanisms developed to accommodate the needs in a certain environment. (e.g., Vulkan and Jennings, 2000; Jones and Koehler, 2002), and different matching mechanisms are necessary under different circumstances (Wurman et al., 1998). According to the dynamic capability theory (Teece et al., 1997; Luo, 2000; Zollo and Winter, 2002; 
Zoot, 2003; Wang and Ahmed, 2007; Richey and Daugherty, 2007; Wang, 2010), enterprise competitiveness also generates from organizational mechanisms, adaptation to the external environment, promotion of change, and development of the enterprise.

Therefore, in this paper, we consider that competitiveness of logistics enterprises results from three aspects: corporate resources, corporate capabilities, and the dynamic mechanism. The corporate resources are the basis, the corporate capabilities are the key factors, and the dynamic mechanism is indispensable for the enterprise to adapt to the external environment. The detailed composing factors of LEC are further discussed in the framework of corporate resources, corporate capabilities, and the dynamic mechanism. Moreover, as competitiveness of firms is normally studied from three hierarchies of strategy, tactics, and operations (Ambastha and Momaya, 2004), in this paper, the corporate capabilities aspect of the composing factors of LEC is discussed from capabilities of a strategical level, tactical level, and operational level. According to the dynamic development opinion (Eisenhardt and Martin, 2000; Bowman and Ambrosi, 2003), the corporate resources aspect of the composing factors of LEC is further classified into static resources and dynamic resources.

Based on the analytical framework and further classification of the composing factors of LEC illustrated above, the comprehensive composing factors of LEC are presented in Table 2. The composing factors take on a three-layer structure. The first layer of composing factors include corporate capabilities, corporate resources, and the dynamic mechanism. Within corporate capabilities, the second layer is further classified according to the managerial level of the strategic, tactical, and operational capabilities, and there are 14 capabilities in the third layer. Within corporate resources, the second layer of composing factors has two different types of factors, which are static resources and dynamic resources, and eight resources are considered in the third layer. Within dynamic mechanism, the third layer is comprised of motive mechanism, learning mechanism, and reaction mechanism. Table 2 also explains the implications of the third-layer composing factors in detail. 
Table 2. The composing factors of LEC

\begin{tabular}{|c|c|c|c|c|}
\hline $\begin{array}{l}\text { First-layer } \\
\text { factors }\end{array}$ & $\begin{array}{l}\text { Second-layer } \\
\text { factors }\end{array}$ & Third-layer factors & $\begin{array}{c}\text { Third-layer factors } \\
\text { discussed by the related } \\
\text { logistics literature }\end{array}$ & Explanation of third-layer factors \\
\hline \multirow{7}{*}{$\begin{array}{l}\text { Corporate } \\
\text { capabilities } \\
\text { (CC) }\end{array}$} & $\begin{array}{c}\text { Capabilities based } \\
\text { on strategic level }\end{array}$ & $\begin{array}{l}\text { Strategic capability } \\
\quad \text { (SC) }\end{array}$ & $\begin{array}{l}\text { Gunasekaran and Ngai } \\
\text { (2003, 2004); } \\
\text { Wang(2006); Liu et } \\
\text { al.(2010) }\end{array}$ & $\begin{array}{l}\text { Strategic foreseeing capability, strategic } \\
\text { positioning capability, and strategic } \\
\text { organizational capability, etc. }\end{array}$ \\
\hline & \multirow{3}{*}{$\begin{array}{l}\text { Capabilities based } \\
\text { on tactical level }\end{array}$} & $\begin{array}{l}\text { Learning capability } \\
\text { (LC) }\end{array}$ & Ratten (2004) & $\begin{array}{c}\text { The capabilities of getting, absorbing and } \\
\text { using knowledge }\end{array}$ \\
\hline & & $\begin{array}{l}\text { Innovation capability } \\
\text { (IC) }\end{array}$ & $\begin{array}{l}\text { Chapman (2003) } \\
\text { Zhen (2008) }\end{array}$ & $\begin{array}{c}\text { Innovation awareness, innovation investment, } \\
\text { innovation organizational capability, and } \\
\text { innovation support capability }\end{array}$ \\
\hline & & $\begin{array}{l}\text { Entrepreneur capability } \\
\text { (EC) }\end{array}$ & Kor and Mesko, (2013) & $\begin{array}{l}\text { Professional dedication, risk awareness, and } \\
\text { organizational coordination ability of the } \\
\text { entrepreneur }\end{array}$ \\
\hline & \multirow{3}{*}{$\begin{array}{l}\text { Capabilities based } \\
\text { on operational } \\
\text { level }\end{array}$} & $\begin{array}{l}\text { Logistics solutions } \\
\text { design capability } \\
\text { ( LSDC) }\end{array}$ & $\begin{array}{l}\text { Daugherty et al., (1998); } \\
\text { Liu et al. (2010) }\end{array}$ & $\begin{array}{l}\text { The solutions designing of capital } \\
\text { investment, management system, and staff } \\
\text { numbers }\end{array}$ \\
\hline & & $\begin{array}{l}\text { Logistics cost control } \\
\text { capability (LCCC) }\end{array}$ & Liu et al. (2010) & $\begin{array}{c}\text { The foreseeing capability, decision capability, } \\
\text { and evaluation capability about the logistics } \\
\text { cost }\end{array}$ \\
\hline & & $\begin{array}{l}\text { Logistics quality control } \\
\text { capability (LQCC) }\end{array}$ & $\begin{array}{l}\text { Harding, F.E. (1998) } \\
\text { Beinstock et al (2008); } \\
\text { Liu et al. (2010) }\end{array}$ & $\begin{array}{c}\text { The comprehensive involvement and } \\
\text { management of the logistics service quality } \\
\text { controlling, and continuous improvement } \\
\text { capability }\end{array}$ \\
\hline
\end{tabular}




\begin{tabular}{|c|c|c|c|c|}
\hline & & $\begin{array}{l}\text { Logistics resources } \\
\text { integrate capability } \\
\text { (LRIC) }\end{array}$ & $\begin{array}{l}\text { Chiu (1995); Liu et al. } \\
\text { (2010) }\end{array}$ & $\begin{array}{c}\text { The integrated capabilities of customer } \\
\text { resource, operating resource, and information } \\
\text { resource }\end{array}$ \\
\hline & & $\begin{array}{l}\text { Logistics risk control } \\
\text { capability (LRCC) }\end{array}$ & Liu et al.(2010) & $\begin{array}{l}\text { The capabilities of risk warning, risk } \\
\text { avoidance, risk response, and risk summary }\end{array}$ \\
\hline & & $\begin{array}{l}\text { Logistics marketing } \\
\text { capability (LMC) }\end{array}$ & $\begin{array}{l}\text { Liu et al. (2010); } \\
\text { Su et al. (2013) }\end{array}$ & $\begin{array}{l}\text { The capabilities of collecting market } \\
\text { information, sales planning, customer } \\
\text { channels controlling, and after-sales } \\
\text { supporting }\end{array}$ \\
\hline & & $\begin{array}{l}\text { Departmental } \\
\text { coordination capability } \\
\text { (DCC) }\end{array}$ & $\begin{array}{l}\text { Pannayides and So } \\
\qquad(2005) ; \\
\text { Mentzer et al. (2004) }\end{array}$ & $\begin{array}{l}\text { The coordination capabilities of business } \\
\text { sector, market sector, quality sector, } \\
\text { information support sector, human resource } \\
\text { sector, and finance sector }\end{array}$ \\
\hline & & $\begin{array}{l}\text { External interface } \\
\text { coordination capability } \\
\text { (EICC) }\end{array}$ & $\begin{array}{c}\text { Larson and Kulchitsky, } \\
\text { (1999). Pannayides and } \\
\text { So (2005); Liu et al. } \\
\text { (2010) }\end{array}$ & $\begin{array}{l}\text { The coordination capabilities of customers } \\
\text { and enterprise, suppliers and enterprise, } \\
\text { government and enterprise }\end{array}$ \\
\hline & & $\begin{array}{l}\text { Human resource } \\
\text { management capability } \\
\text { (HRMC) }\end{array}$ & Liu et al. (2010) & $\begin{array}{l}\text { The human resource system planning, } \\
\text { development mechanism, rewards and } \\
\text { penalties system, and promotion system }\end{array}$ \\
\hline & & $\begin{array}{l}\text { Financial management } \\
\text { capability (FMC) }\end{array}$ & Yeung (2006) & $\begin{array}{l}\text { Financial analysis capability and corporate } \\
\text { finance capability }\end{array}$ \\
\hline \multirow{2}{*}{$\begin{array}{l}\text { Corporate } \\
\text { resources }(\mathrm{CR})\end{array}$} & \multirow[b]{2}{*}{ Static resources } & $\begin{array}{c}\text { Logistics facilities and } \\
\text { equipment resources } \\
\text { (LFER) }\end{array}$ & Chiu (1995) & $\begin{array}{l}\text { Advanced equipment and the equipment } \\
\text { scales }\end{array}$ \\
\hline & & $\begin{array}{l}\text { Logistics information } \\
\text { technology resources } \\
\text { (LITR) }\end{array}$ & $\begin{array}{c}\text { Alshawi (2001). } \\
\text { Gunasekaran and Ngai } \\
\text { (2003, 2004); Liu et al. } \\
\text { (2010); Su et al. (2013) }\end{array}$ & Advanced logistics IT \\
\hline
\end{tabular}




\begin{tabular}{|c|c|c|c|c|}
\hline & & $\begin{array}{l}\text { Logistics network } \\
\text { resources (LNR) }\end{array}$ & $\begin{array}{l}\text { Creazza et al (2010); } \\
\quad \text { Liu et al. (2010) }\end{array}$ & $\begin{array}{l}\text { The number, density, and scale of the } \\
\text { logistics network }\end{array}$ \\
\hline & & $\begin{array}{l}\text { Logistics customer } \\
\text { resources }(\mathrm{LCR})\end{array}$ & $\begin{array}{c}\text { Pannayides and So } \\
(2005) ; \\
\text { Gunasekaran and Ngai } \\
(2003,2004)\end{array}$ & $\begin{array}{l}\text { Customer number, customer brand, and } \\
\text { customer relationship }\end{array}$ \\
\hline & & $\begin{array}{l}\text { Corporate financial } \\
\text { resources (CFR) }\end{array}$ & Yeung (2006) & $\begin{array}{l}\text { The registered capital, net assets, and } \\
\text { financing channels of the corporate }\end{array}$ \\
\hline & & $\begin{array}{l}\text { Corporate human } \\
\text { resources (CHR) }\end{array}$ & Liu et al. (2010) & Advanced staff and managers \\
\hline & Dynamic & $\begin{array}{l}\text { Knowledge and } \\
\text { information resources } \\
(\mathrm{KIR})\end{array}$ & $\begin{array}{l}\text { Liu et al. (2007a) } \\
\text { Liu et al. (2007b) } \\
\text { Beinstock et al. (2008); } \\
\text { Liu et al. (2010) }\end{array}$ & $\begin{array}{l}\text { The experience of management, the } \\
\text { information network, and the special } \\
\text { information channel }\end{array}$ \\
\hline & & $\begin{array}{l}\text { Corporate culture } \\
\text { resources }(\mathrm{CCR})\end{array}$ & $\begin{array}{l}\text { Liu et al. (2007a) } \\
\text { Liu et al. (2007b) } \\
\text { Liu et al. (2010) }\end{array}$ & $\begin{array}{c}\text { The operation principle, cohesive force, and } \\
\text { shared vision of the corporate }\end{array}$ \\
\hline \multirow{3}{*}{$\begin{array}{l}\text { Dynamic } \\
\text { mechanism } \\
(\mathrm{DM})\end{array}$} & \multirow{3}{*}{$\begin{array}{l}\text { Dynamic } \\
\text { mechanism }\end{array}$} & $\begin{array}{l}\text { Motive mechanism } \\
\qquad(\mathrm{MM})\end{array}$ & $\begin{array}{l}\text { Persson (1997) } \\
\text { Ralston et al. (2013) }\end{array}$ & $\begin{array}{c}\text { Organization structure mechanism, decision } \\
\text { mechanism and incentive, and restraint } \\
\text { mechanism }\end{array}$ \\
\hline & & $\begin{array}{l}\text { Learning mechanism } \\
\qquad(\mathrm{LM})\end{array}$ & $\begin{array}{l}\text { Gudmundsson and } \\
\text { Nijhuis, (2001) } \\
\text { Ratten (2004); } \\
\text { Ralston et al.(2013) }\end{array}$ & $\begin{array}{l}\text { The learning organization, the number of } \\
\text { corporation training. and the corporate } \\
\text { learning system }\end{array}$ \\
\hline & & $\begin{array}{l}\text { Reaction mechanism } \\
\qquad(\mathrm{RM})\end{array}$ & Ding et al. (2013) & $\begin{array}{l}\text { The quick response to the customer, } \\
\text { competitor, and market }\end{array}$ \\
\hline
\end{tabular}


4.2 Three-dimension analysis framework of LECIn this paper, LEC is analyzed from three dimensions, namely, competitiveness factor dimension, enterprise type dimension and life cycle dimension, which all have an influence on LEC.

- Competitiveness factor dimension: There are three aspects of competitiveness factors of LEC, which include the factors of dynamic mechanism (FDM), the factors of corporate resources (FCR), and the factors of corporate capabilities (FCC).

- Enterprise type dimension: There are four types of Chinese logistics enterprises, which include platform logistics company (PLLC), universal logistics company (ULC), professional logistics company (PRLC) and supply chain management company (SCMC).

- Life cycle dimension: There are four stages in the life cycle of a logistics enterprise, which include initial stage (IS), growth stage (GS), maturity stage (MS) and regeneration stage (RS).

\section{Survey on the composing factors of LEC}

\subsection{Questionnaire design and variable measurement}

This study adopts a self-designed questionnaire based on literature review (Shmuel and Noga, 2003; Frenandez et al., 2000; Zahra and Neubaum, 2003; Thomas and Harrington, 2003; Calantone and Cavusgil, 2003; Lai, 2004; Liu et al., 2010; and Wang, 2010). The primary contents of the questionnaire include two parts, which are the basic company data survey and the logistics enterprise competitiveness survey. The basic company data survey investigates the type of the logistics company, the development stages of the company, and other basic enterprise information. The logistics enterprise competitiveness survey investigates the importance of the composing factors of LEC, including the three competitiveness factors of corporate capabilities, corporate resources, and the dynamic mechanism. It should be noted that the questionnaire asks the respondents to answer intuitively, thus the perception of the importance of the composing factors of LEC might vary among the respondents. By conducting this survey, we sought to analyze the importance of the composing factors of LEC in consideration of the type and development stage of the logistics enterprise, and thus suggest effective evolutionary paths for the composing factors of LEC for logistics enterprises of various types and life cycle stages.

\subsection{Data sampling}

\subsubsection{Survey area}

Funded by the National Natural Science Foundation of China, the survey began in December 2010 and ended in May 2011. To gain a comprehensive understanding of LEC in China, the survey was conducted in three ways, as shown in Table 3.

Table 3. Profile of the questionnaire survey

\begin{tabular}{cccc}
\hline Form & Scope of survey & $\begin{array}{c}\text { Questionnaires } \\
\text { Issued }\end{array}$ & $\begin{array}{c}\text { Questionnaires } \\
\text { returned }\end{array}$ \\
\hline Email & The survey questionnaires were emailed to & 660 & 58 \\
\hline
\end{tabular}




\begin{tabular}{|c|c|c|c|}
\hline & $\begin{array}{l}\text { companies located in northeast, northwest, } \\
\text { north, central, east, south, and southwest } \\
\text { China. }\end{array}$ & & \\
\hline $\begin{array}{l}\text { Survey } \\
\text { conducted } \\
\quad \text { in a } \\
\text { conference }\end{array}$ & $\begin{array}{l}\text { Questionnaires were issued in the following } \\
\text { conferences: "2011 China Logistics } \\
\text { Development Conference," "2011 China } \\
\text { Logistics University-Industry-Science } \\
\text { Institute Partnership Conference," and "2011 } \\
\text { Beijing Global Purchasing and Supply Chain } \\
\text { Conference." }\end{array}$ & 300 & 54 \\
\hline $\begin{array}{l}\text { Survey } \\
\text { conducted } \\
\text { in class }\end{array}$ & $\begin{array}{l}\text { Questionnaires were issued to on-the-job } \\
\text { postgraduates of Logistics in Tianjin } \\
\text { University and Nankai University, China. }\end{array}$ & 200 & 124 \\
\hline \multicolumn{4}{|c|}{$\begin{array}{l}\text { A total of } 1160 \text { questionnaires were sent and } 236 \text { questionnaires were returned, of which } 220 \\
\text { forms were valid. The respondent rate was } 20.34 \% \text {, and the effective rate was } 93.22 \% \text {. The } \\
\text { respondent rates of east, south, and north China were higher, which is a consequence of the } \\
\text { imbalance of regional economic development. East, south, and north China are developed regions, } \\
\text { where the logistics enterprises are relatively mature. Therefore, the respondents in these areas had } \\
\text { greater enthusiasm in returning the questionnaires. }\end{array}$} \\
\hline
\end{tabular}

\subsubsection{Characteristics of the survey data}

Table 4 shows the profile of the respondents according to the survey data.

Table 4. Profile of the respondents $(n=220)$

\begin{tabular}{|c|c|c|c|}
\hline & Type & Number & Percent \\
\hline \multirow{4}{*}{$\begin{array}{c}\text { Type of } \\
\text { enterprise }\end{array}$} & PLLC & 48 & 21.82 \\
\hline & ULC & 82 & 37.27 \\
\hline & PRLC & 47 & 21.36 \\
\hline & SCMC & 43 & 19.55 \\
\hline \multirow{4}{*}{$\begin{array}{c}\text { Enterprise } \\
\text { development } \\
\text { stage }\end{array}$} & Initial stage & 12 & 5.45 \\
\hline & Growth stage & 100 & 45.45 \\
\hline & Maturity stage & 62 & 28.19 \\
\hline & Regeneration stage & 46 & 20.91 \\
\hline \multirow{7}{*}{ Survey area } & Northeast China & 15 & 9.09 \\
\hline & North China & 38 & 21.82 \\
\hline & Central China & 10 & 12.73 \\
\hline & South China & 40 & 18.18 \\
\hline & East China & 46 & 20.91 \\
\hline & Southwest China & 20 & 11.36 \\
\hline & Northwest China & 12 & 5.91 \\
\hline Annual revenue & Less than 10 million & 42 & 19.09 \\
\hline
\end{tabular}




\begin{tabular}{|c|c|c|c|}
\hline \multirow{4}{*}{$\begin{array}{l}\text { in logistics field } \\
\text { (RMB) }\end{array}$} & 10-50million & 75 & 34.09 \\
\hline & 51-100 million & 19 & 8.64 \\
\hline & More than 100 million & 70 & 31.82 \\
\hline & Other & 14 & 6.36 \\
\hline \multirow{6}{*}{$\begin{array}{l}\text { Number of } \\
\text { employees }\end{array}$} & Less than 100 & 52 & 23.64 \\
\hline & $101-500$ & 41 & 18.64 \\
\hline & $501-1000$ & 72 & 32.73 \\
\hline & $1001-5000$ & 33 & 15.00 \\
\hline & $5001-10000$ & 12 & 5.45 \\
\hline & More than 10000 & 10 & 4.55 \\
\hline \multirow{4}{*}{$\begin{array}{c}\text { Working years } \\
\text { in the logistics } \\
\text { company }\end{array}$} & Less than 3 years & 55 & 25.00 \\
\hline & $3-5$ years & 51 & 23.18 \\
\hline & $6-7$ years & 47 & 21.36 \\
\hline & More than 8 years & 67 & 30.45 \\
\hline \multirow{4}{*}{$\begin{array}{c}\text { Current position } \\
\text { of the } \\
\text { interviewee }\end{array}$} & Staff & 55 & 25.00 \\
\hline & Supervisor & 43 & 19.55 \\
\hline & Manager & 63 & 28.64 \\
\hline & Senior manager & 59 & 26.82 \\
\hline
\end{tabular}

\subsection{Sampling unbiased test and reliability test}

A sampling unbiased test was conducted to check whether the survey is representative. The unbiased test measures whether there is statistical deviation among the respondents and non-respondents of the survey targets.

Sampling twice is one of the approaches of the unbiased test. In this approach, the initial sampling is performed and then a second sampling is conducted for the no-response (those who did not participate in the initial survey) in the sample group. The $t$ test is used to examine whether the responses of the two samples (those who participated and those who did not participate in the survey) to the questionnaire are different. Another approach involves dividing the samples into two sample groups (two waves) by a natural wave dividing line of the sample response time. A comparison test ( $t$ test) is then performed to determine whether there are differences between the two sample groups. This paper adopts the second approach. The test results show that the $t$ values of all indexes are greater than 0.5 and that the value of Sig. (2-tailed) is greater than 0.45 . Hence, the sample has no statistically significant difference $(\mathrm{P}<0.05)$, making it unbiased.

Validity analysis of the questionnaires is performed after obtaining the responses of the questionnaires. This paper adopts the reliability test method using the Cronbach's coefficient $\alpha$. By using Statistical Product and Service Solutions (SPSS15.0) software, the reliability test is executed for the assumption variables in Table 1 . The reliability degree of any variable showed in Table 1 is more than 0.8 . The overall reliability is 0.854 , which is acceptable. The result shows that the design of the assumption variables in the questionnaires and the survey results are consistent and 
reliable.

\section{Importance of the composing factors on LEC}

\subsection{The importance of composing factors on LEC}

Based on the survey results, we conduct statistical analysis to explore the importance of corporate capabilities, resources, and dynamic mechanism on LEC. The SPSS 15.0 software is used in the structural model analysis, which can determine the effect of each composing factor on LEC. The LEC refers to the exogenous variables of the model. Corporate capabilities, corporate resources, and the dynamic mechanism are the endogenous variables. These endogenous variables consist of several observed variables. The standardized parameter between the observed variables and endogenous variables is the factor loading. The standardized parameter of the endogenous and exogenous variables is the result of the regression analysis, shown in Figure 1.

As shown in Figure 1, the standardized parameters of corporate capabilities, corporate resources, and the dynamic mechanism are 0.952, 0.913, and 0.896, respectively. The result shows that the values of the standardized parameters of the three endogenous variables are very close and high, indicating the significant influence of these three endogenous variables on LEC. The results also present that the endogenous variable of corporate capabilities is the most important for LEC, the next important endogenous variable are corporate resources, and the last is the dynamic mechanism. This implies that corporate capabilities should garner more attention than the other two factors. 


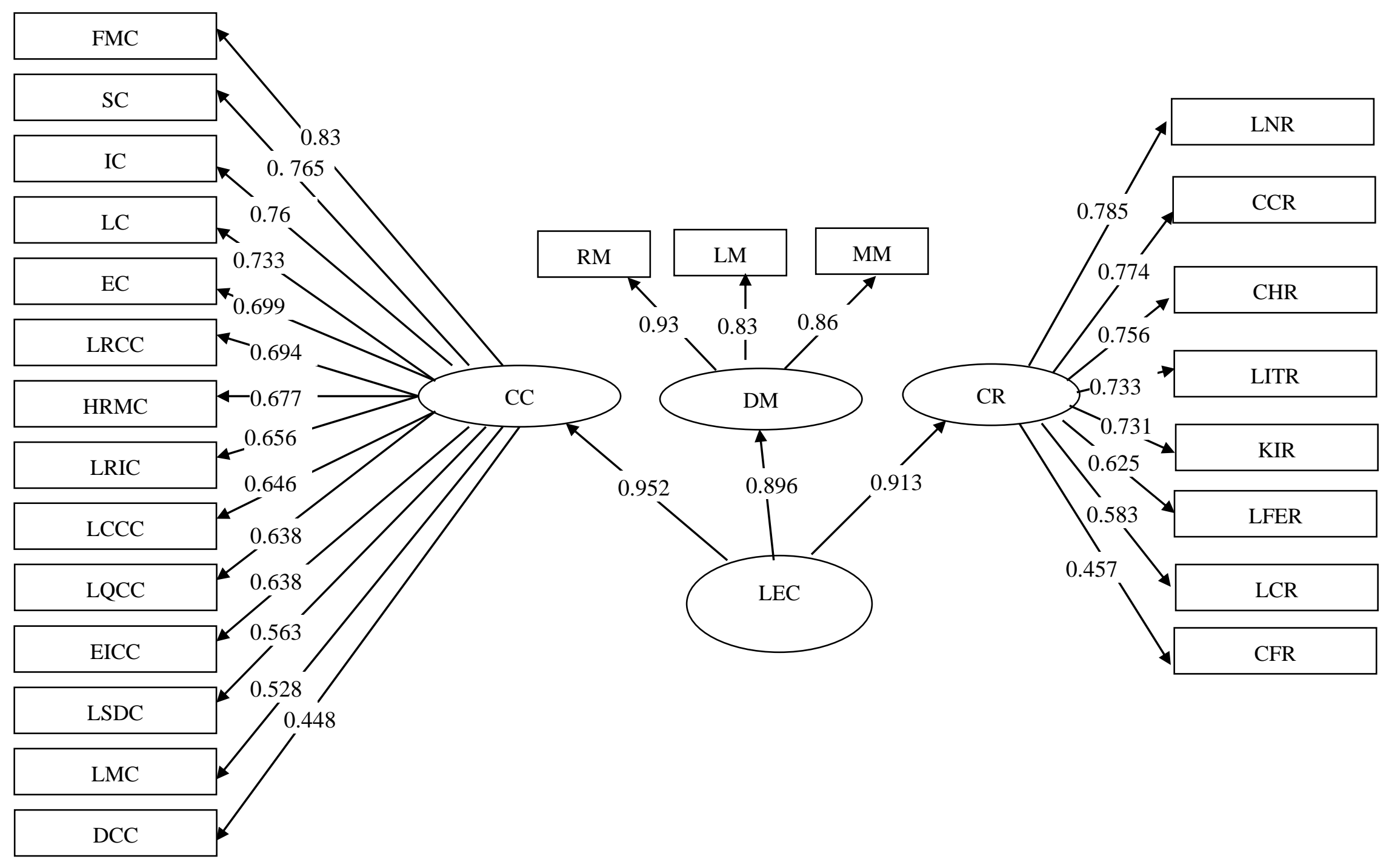

Fig. 1. Standardized parameters of LEC composing factors 
Regarding the endogenous variable of the corporate capabilities, Table 5 shows the value of the standardized parameters of 14 observed variables. It is obvious that financial management capability has the greatest parameter value, indicating that it is the most important LEC factor. The parameter values also demonstrate that factors of strategic capability, innovation capability, learning capability, and entrepreneur capability are of great significance to LEC.

With regard to the endogenous variable of corporate resources, Table 5 shows the value of the standardized parameters of eight observed variables. Logistics network resources, corporate culture resources, and human resources are the most important positions of the resource system, and the factor of the logistics network resources is the most essential of the eight observed resources. The importance of corporate culture resources is actually underestimated by the value of the correspondent parameter, since it is a slow variable and would have an increasingly greater impact on LEC from the dynamic perspective. As shown in Table 5, logistics information technology resources are important as well and deserve attention.

As to the endogenous variable of the dynamic mechanism, Table 5 shows the standardized parameters of three observed variables. The scores of the mechanisms in reaction, motive, and learning are $0.93,0.86$, and 0.83 , respectively. The uncertain and rapidly changing competitive environment makes the reaction mechanism important to the development of logistics enterprises in China. In addition, the motive mechanism also plays an important role in promoting the development of LEC.

Table 5. The importance of the composing factors on LEC

\begin{tabular}{ccccccccc}
\hline $\begin{array}{c}\text { Corporate } \\
\text { capabilities }\end{array}$ & $\begin{array}{c}\text { Standardized } \\
\text { Parameter } \\
\text { value }\end{array}$ & Rank & $\begin{array}{c}\text { Corporate } \\
\text { resources }\end{array}$ & $\begin{array}{c}\text { Standardized } \\
\text { Parameter } \\
\text { value }\end{array}$ & Rank & $\begin{array}{c}\text { Dynamic } \\
\text { mechanism }\end{array}$ & $\begin{array}{c}\text { Standardized } \\
\text { Parameter } \\
\text { value }\end{array}$ & Rank \\
\hline FMC & 0.83 & 1 & LNR & 0.785 & 1 & RM & 0.93 & 1 \\
\hline SC & 0.765 & 2 & CCR & 0.774 & 2 & MM & 0.86 & 2 \\
\hline IC & 0.76 & 3 & CHR & 0.756 & 3 & LM & 0.83 & 3 \\
\hline LC & 0.733 & 4 & LITR & 0.733 & 4 & & \\
\hline EC & 0.699 & 5 & KIR & 0.731 & 5 & & \\
\hline LRCC & 0.694 & 6 & LFER & 0.625 & 6 & & \\
\hline HRMC & 0.677 & 7 & LCR & 0.583 & 7 & & \\
\hline LRIC & 0.656 & 8 & CFR & 0.457 & 8 & & \\
\hline LCCC & 0.646 & 9 & & & & & \\
\hline LQCC & 0.638 & 10 & & & & & \\
\hline EICC & 0.638 & 10 & 12 & & & & \\
\hline LSDC & 0.563 & &
\end{tabular}




\begin{tabular}{ccc}
\hline LMC & 0.528 & 13 \\
\hline DCC & 0.448 & 14 \\
\hline
\end{tabular}

To obtain a clear understanding of the reality of LEC for Chinese logistics enterprises, the comparison of the mean of the LEC composing factors is required. Table 6 shows the detailed results.

Table 6. The mean of the composing factors of LEC

\begin{tabular}{|c|c|c|c|c|c|c|c|c|}
\hline $\begin{array}{l}\text { Corporate } \\
\text { capabilities }\end{array}$ & $\begin{array}{c}\text { Standardized } \\
\text { Parameter } \\
\text { value }\end{array}$ & Rank & $\begin{array}{l}\text { Corporate } \\
\text { resources }\end{array}$ & $\begin{array}{c}\text { Standardized } \\
\text { Parameter } \\
\text { value }\end{array}$ & Rank & $\begin{array}{l}\text { Dynamic } \\
\text { mechanism }\end{array}$ & $\begin{array}{c}\text { Standardized } \\
\text { Parameter } \\
\text { value }\end{array}$ & Rank \\
\hline LQCC & 5.89 & 1 & LCR & 5.93 & 1 & $\mathrm{RM}$ & 5.97 & 1 \\
\hline SC & 5.86 & 2 & LNR & 5.69 & 2 & MM & 5.43 & 2 \\
\hline IC & 5.81 & 3 & CFR & 5.63 & 3 & LM & 5.3 & 3 \\
\hline EC & 5.66 & 4 & LITR & 5.58 & 4 & & & \\
\hline LRIC & 5.65 & 5 & KNR & 5.35 & 5 & & & \\
\hline LC & 5.60 & 6 & CCR & 5.28 & 6 & & & \\
\hline $\mathrm{LCCC}$ & 5.60 & 6 & CHR & 5.26 & 7 & & & \\
\hline DCC & 5.59 & 7 & LFER & 5.13 & 8 & & & \\
\hline EICC & 5.58 & 8 & & & & & & \\
\hline LRCC & 5.43 & 10 & & & & & & \\
\hline LMC & 5.40 & 11 & & & & & & \\
\hline LSDC & 5.36 & 12 & & & & & & \\
\hline FMC & 5.29 & 13 & & & & & & \\
\hline HRMC & 5.11 & 14 & & & & & & \\
\hline
\end{tabular}

Table 7 is an integration of Tables 5 and 6 . The importance rank is taken from Table 5, and the mean rank is derived from Table 6. Figs. 2 and 3 are the visual illustrations of Table 7.

Table 7. The comprehensive analysis of the composing factors of LEC

\begin{tabular}{ccccccccc}
\hline $\begin{array}{c}\text { Corporate } \\
\text { capability }\end{array}$ & $\begin{array}{c}\text { Importance } \\
\text { rank }\end{array}$ & $\begin{array}{c}\text { Mean } \\
\text { rank }\end{array}$ & $\begin{array}{c}\text { Corporate } \\
\text { resources }\end{array}$ & $\begin{array}{c}\text { Importance } \\
\text { rank }\end{array}$ & $\begin{array}{c}\text { Mean } \\
\text { rank }\end{array}$ & $\begin{array}{c}\text { Dynamic } \\
\text { mechanism }\end{array}$ & $\begin{array}{c}\text { Importance } \\
\text { rank }\end{array}$ & $\begin{array}{c}\text { Mean } \\
\text { rank }\end{array}$ \\
\hline FMC & 1 & 13 & LNR & 1 & 2 & RM & 1 & 1 \\
\hline SC & 2 & 2 & CCR & 2 & 6 & MM & 2 & 2 \\
\hline IC & 3 & 3 & CHR & 3 & 7 & LM & 3 & 3 \\
\hline LC & 4 & 6 & LITR & 4 & 4 & & & \\
\hline
\end{tabular}




\begin{tabular}{cccccc}
\hline EC & 5 & 4 & KNR & 5 & 5 \\
\hline LRCC & 6 & 10 & LFER & 6 & 8 \\
\hline HRMC & 7 & 14 & LCR & 7 & 1 \\
\hline LRIC & 8 & 5 & CFR & 8 & 3 \\
\hline LCC & 9 & 6 & & & \\
\hline LQCC & 10 & 1 & & & \\
\hline EICC & 10 & 8 & & \\
\hline LSDC & 12 & 12 & & \\
\hline LMC & 13 & 11 & & \\
\hline DCC & 14 & 7 &
\end{tabular}

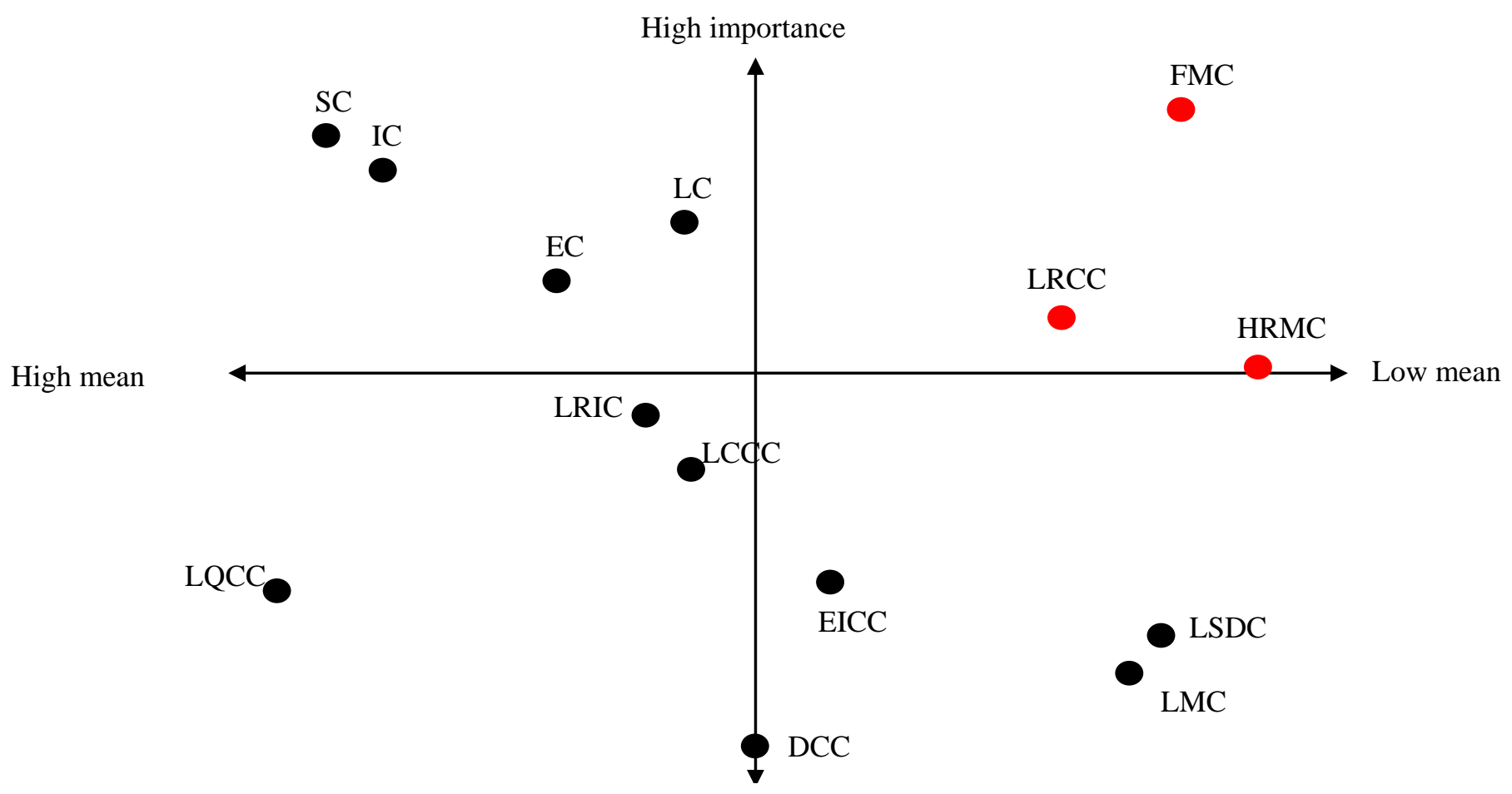

Low importance

Fig. 2. Corporate capabilities and competitiveness 


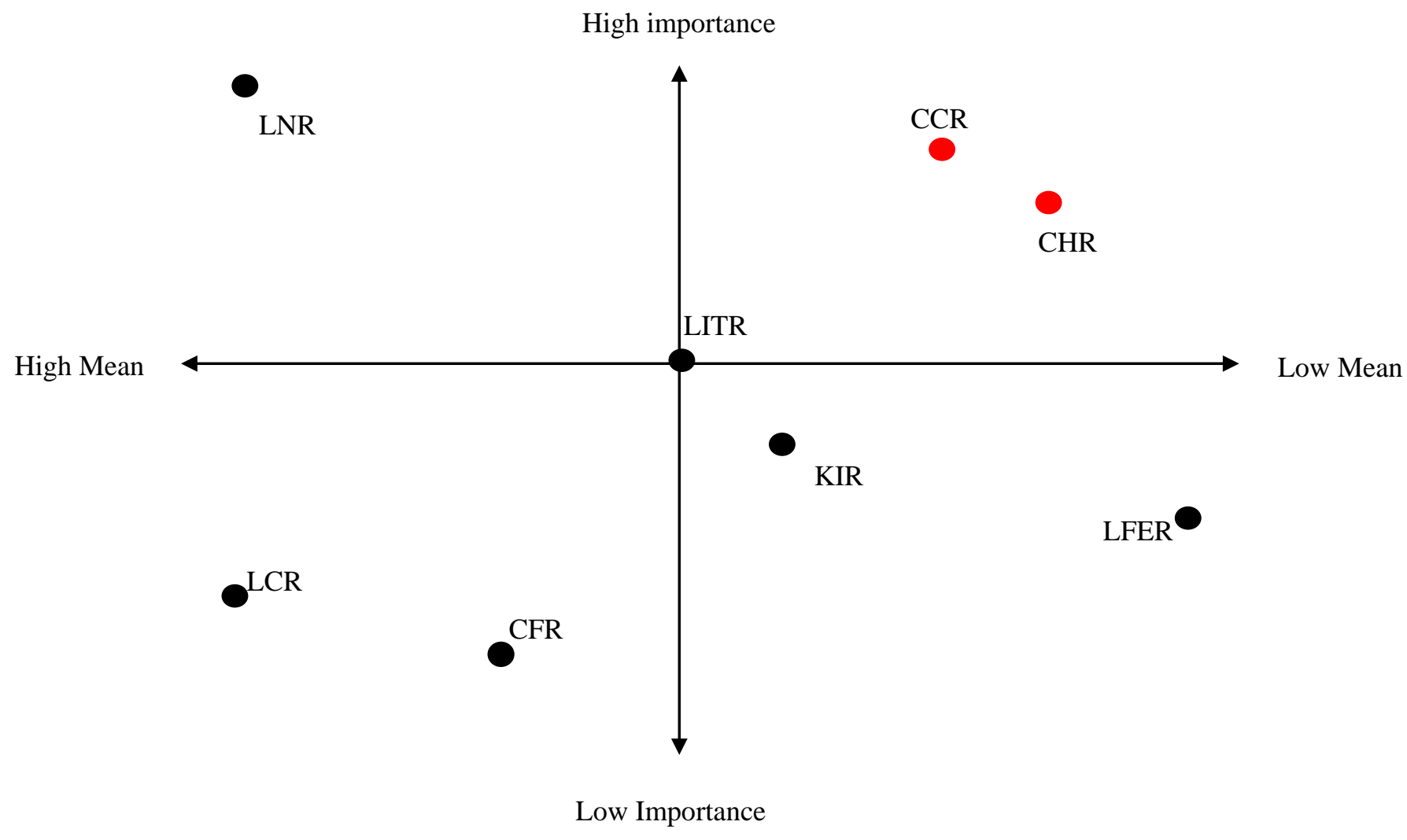

Fig. 3. Corporate resources and competitiveness

\subsection{Improvement suggestions for development of LEC}

Figures 2 and 3 show the distribution of corporate capabilities and resources into four quadrants. The factors distributed in the first quadrant are the most important factors, but, in practice, they are usually the weaknesses of enterprises. The following discussion focuses on these factors.

(1) Financial management capability. Financial management capability is the most important factor, but it shows poor performance in the mean rank (ranked 13). This phenomenon is largely caused by the lack of financial management awareness in logistics enterprises. In China, the main task of many Chief Financial Officers is performing basic accounting. The financial leverage function does not gain much attention. Moreover, enterprises put much effort on short-term rather than long-term profit, thus it is difficult to show the advantages of financial management capability.

(2) Logistics risk control capability. The logistics risk control capability is an indispensible guarantee for enterprise profits in a competitive environment. From the empirical analysis result, the mean of the logistics risk control capability is low, thus Chinese logistics enterprises should strengthen awareness of logistics risk control.

(3) Corporate human resources and human resources management capability. The corporate human resources factor ranks third in importance and seventh in mean, respectively; human resources management capability ranks seventh in importance and fourteenth in mean. This 
implies that there is still much room for improvement for these two LEC factors. In the knowledge economy era, the defects of corporate human resources and human resources management capability would limit the long-term development of enterprises. Therefore, the management of human resources receives adequate attention.

(4) Corporate culture resources. The factor of corporate culture resources ranks second in importance and sixth in the mean rank list. In general, corporate culture is a basic belief accepted and shared by all employees. Aside from referring to the values and development targets of the enterprise, corporate culture is also a mechanism used to motivate the staff. Although the process of corporate culture contributing to competitiveness is slow, its function and effectiveness is irreplaceable and lasting; thus logistics enterprises should be more concerned with corporate culture resources.

\section{Comparisons of composing factors and evolution processes}

\subsection{Comparison of the LEC composing factors among the different types of logistics enterprises}

In this section, the importance of composing factors and their evolution processes are discussed based on the different types of logistics enterprises.

From the perspective of the rank of corporate capabilities, the PLLC and SCMC regard strategic capability as the most important factor, as shown in Table 8, indicating that strategic capability is vital to the long-term development of these two types of logistics enterprises. The ULC emphasizes entrepreneur capability, because the ULC is mainly a small-scale private business. This type of logistics company is widespread in China; thus, the company leader's ability plays a great importance on the future development of the company. The PRLC gives more attention to logistics quality control capability, implying that quality control capability is the core of the capabilities system of the PRLC.

With regard to the rank of corporate resources, Table 8 presents that customer resource is the most important resource for all types of logistics enterprises. The PLLC, ULC, and SCMC regard logistics network resources as the second most important resource, while the PRLC considers financial resources as the second most important resource. Financial resources have greater weight than logistics network resources for the PRLC, as its financial demand for purchasing equipment is much more than the other three types of logistics companies. Logistics information technology resources rank the fourth in the resource system of the four types of enterprises, and deserves consideration.

From the view of the rank of dynamic mechanism, Table 8 shows that reaction mechanism ranks first for all kinds of logistics enterprises. The PLLC, ULC, and PRLC regard motive mechanism as the second most important mechanism, while the SCMC considers learning mechanism as the second most important mechanism. This finding implies that SCMC should pay more attention to 
the learning capability of external knowledge and the integration capability of the entire supply chain.

As for the rank of corporate competitiveness factors, Table 10 illustrates that the PLLC and ULC treat corporate resources as the most important factor in the corporate competitiveness system. In contrast, the PRLC and SCMC consider corporate capabilities as the most essential factor.

\subsection{Evolution of composing factors considering the type and development stage of the logistics enterprise}

Regarding the rank of corporate capabilities, Table 9 shows that strategic capability is most important at the initial stage. With the development of the enterprise, the importance of strategic capability begins to decrease, whereas the importance of logistics quality control and innovation capabilities begins to increase. The strategic and departmental coordination capabilities are indispensable in the development of corporate business, therefore, they rank in the top seven at all stages. Entrepreneur capability is especially important at the initial and maturity stages, as this capability generates vision and revolutionary power. Resource integration capability becomes more essential at the maturity stage, as there is a lack of scale advantage at the initial and growth stages; the integration effect of lower cost and more flexibility emerges at the maturity stage.

With regard to the rank of corporate resources, Table 9 presents that logistics customer resource is the first important at the initial, growth, and regeneration stages. Logistics information technology resource becomes the most crucial factor at the maturity stage as customer resource has accumulated to a considerable level at the maturity stage and the information technology resource plays a critical role in a firm's effort to improve logistics service quality. Logistics network resource ranks the third at the initial and growth stages, which indicates that logistics enterprises should pay sufficient attention to networking construction before its maturity stage. Moreover, corporate financial resource is very important at the initial, growth, and maturity stages. The importance of corporate culture resource begins to emerge at the maturity and regeneration stages, as corporate culture resource is beneficial to the rapid development of logistics enterprises in the new round of competition.

From the perspective of dynamic mechanism, Table 9 shows that reaction mechanism is the most important factor of the dynamic mechanism system at all stages, especially at the regeneration stage. This indicates that logistics enterprises think highly of being responsive to customers, competitors, and the market. Overall, motive mechanism weighs more than learning mechanism at the initial, growth, and maturity stages, reflecting the effects of motivation are more positive than that of training in Chinese logistics enterprises.

As shown in Table 10, from the view of corporate competitiveness, corporate capability is the most important factor, followed by dynamic mechanism and corporate resources at the initial, growth, and regeneration stages. The dynamic mechanism becomes the first important factor at the maturity stage, which implies that logistics enterprises should invest more in enterprise innovation and quick response to customers, competitors, and market environment at this stage. 
Table 8. The comprehensive analysis of the composing factors of LEC based on the four types of companies

\begin{tabular}{|c|c|c|c|c|c|c|c|c|c|c|c|c|}
\hline \multirow{2}{*}{ Rank } & \multicolumn{4}{|c|}{ Corporate capabilities } & \multicolumn{4}{|c|}{ Corporate resources } & \multicolumn{4}{|c|}{ Dynamic mechanism } \\
\hline & PLLC & ULC & PRLC & SCMC & PLLC & ULC & PRLC & SCMC & PLLC & ULC & PRLC & SCMC \\
\hline 1 & $\mathrm{SC}(5.85)$ & $\mathrm{EC}(6.15)$ & LQCC (6.65) & $\mathrm{SC}(6.48)$ & LCR (6.67) & LCR (6.75) & LCR (6.35) & LCR (6.52) & RM (5.93) & $\mathrm{RM}(5.88)$ & $\mathrm{RM}(5.79)$ & $\mathrm{RM}(6.28)$ \\
\hline 2 & $\mathrm{IC}(5.62)$ & $\mathrm{SC}(6.06)$ & LRIC (6.22) & LQCC (6.31) & LNR (6.45) & LNR (6.25) & CFR (6.25) & $\operatorname{LNR}(6.35)$ & MM (5.33) & MM (5.63) & MM (5.54) & LM (5.38) \\
\hline 3 & $\mathrm{LC}(5.55)$ & IC (5.94) & $\operatorname{LCCC~(6.13)~}$ & FMC (6.09) & $\begin{array}{l}\text { LITR } \\
(6.21)\end{array}$ & CFR (6.15) & LNR (6.06) & $\begin{array}{l}\text { LITR } \\
(6.21)\end{array}$ & LM (5.24) & LM (5.32) & LM (5.43) & $\operatorname{MM}(5.26)$ \\
\hline 4 & $\mathrm{EC}(5.45)$ & LQCC (5.86) & $\operatorname{DCC}(5.85)$ & DCC (5.97) & CFR (5.93) & $\operatorname{LITR}(5.85)$ & $\begin{array}{c}\text { LITR } \\
(5.75)\end{array}$ & CHR (5.99) & & & & \\
\hline 5 & $\operatorname{LCC}(5.34)$ & $\operatorname{EICC~(5.25)~}$ & $\mathrm{IC}(5.59)$ & $\mathrm{IC}(5.65)$ & & & & & & & & \\
\hline 6 & LQCC (5.16) & LC (5.15) & LRCC(5.25) & $\mathrm{EC}(5.48)$ & & & & & & & & \\
\hline 7 & LRIC (4.85) & LRIC (5.06) & LMC (5.09) & $\mathrm{LC}(5.12)$ & & & & & & & & \\
\hline
\end{tabular}

Note: The top seven corporate capability factors and top four corporate resource factors are included in Table 8. 
Table 9. The comprehensive analysis of the composing factors of LEC based on the four life cycle stages

\begin{tabular}{|c|c|c|c|c|c|c|c|c|c|c|c|c|}
\hline \multirow{2}{*}{ Rank } & \multicolumn{4}{|c|}{ Corporate capabilities } & \multicolumn{4}{|c|}{ Corporate resources } & \multicolumn{4}{|c|}{ Dynamic mechanism } \\
\hline & IS & GS & MS & $\mathrm{RS}$ & IS & GS & MS & $\mathrm{RS}$ & IS & GS & MS & $\mathrm{RS}$ \\
\hline 1 & $\mathrm{SC}(5.85)$ & LQCC (6.04) & LQCC (6.03) & $\mathrm{SC}(6.38)$ & LCR (6.4) & LCR (6.16) & $\begin{array}{c}\text { LITR } \\
(5.83)\end{array}$ & $\operatorname{LCR}(6.0)$ & $\mathrm{RM}(6.0)$ & RM (6.0) & $\mathrm{RM}(5.97)$ & $\mathrm{RM}(6.04)$ \\
\hline 2 & LCCC (5.8) & $\mathrm{SC}(5.98)$ & $\mathrm{EC}(5.93)$ & $\mathrm{IC}(6.25)$ & CFR (6.2) & $\operatorname{LNR}(6.06)$ & LCR (5.7) & $\begin{array}{c}\text { CCR } \\
(5.79)\end{array}$ & MM (5.6) & MM (5.63) & $\mathrm{MM}(5.58)$ & $\operatorname{LM}(5.45)$ \\
\hline 3 & $\mathrm{EC} \mathrm{(5.7)}$ & $\mathrm{IC}(5.89)$ & LRIC(5.73) & $\mathrm{EC}(5.88)$ & LNR (6.0) & LITR (5.77) & CFR (5.65) & KIR (5.58) & $\mathrm{LM}(5.5)$ & $\operatorname{LM}(5.3)$ & $\operatorname{LM}(5.36)$ & $\operatorname{MM}(5.25)$ \\
\hline 4 & $\operatorname{LSDC}(5.65)$ & LRIC (5.87) & $\mathrm{IC}(5.7)$ & $\mathrm{LC}(5.88)$ & LFER (5.8) & CFR (5.73) & $\operatorname{CCR}(5.6)$ & $\operatorname{CHR}(5.54)$ & & & & \\
\hline 5 & LRIC (5.55) & $\operatorname{LCCC}(5.77)$ & $\operatorname{LCCC}(5.65)$ & $\operatorname{EICC~(5.70)~}$ & & & & & & & & \\
\hline 6 & $\operatorname{LMC}(5.45)$ & EICC (5.75) & $\mathrm{SC}(5.6)$ & $\operatorname{LQCC}(5.63)$ & & & & & & & & \\
\hline 7 & $\operatorname{DCC}(5.4)$ & DCC (5.70) & $\operatorname{DCC}(5.53)$ & $\operatorname{DCC}(5.5)$ & & & & & & & & \\
\hline
\end{tabular}

Note: The top seven corporate capability factors and top four corporate resource factors are involved in Table 9. 
Table 10. The rank of the competitiveness factors

\begin{tabular}{|c|c|c|c|c|c|c|c|c|}
\hline \multirow{2}{*}{ Rank } & \multicolumn{4}{|c|}{ The rank based on the scope of company type } & \multicolumn{4}{|c|}{ The rank based on the scope of life cycle stage } \\
\hline & PLLC & ULC & PRLC & SCMC & IS & GS & MS & $\mathrm{RS}$ \\
\hline 1 & CR (5.60) & CR (5.57) & $\mathrm{CC}(5.81)$ & $\mathrm{CC}(5.78)$ & $\mathrm{CC}(5.6)$ & $\mathrm{CC}(5.93)$ & $\mathrm{DM}(5.76)$ & $\mathrm{CC}(5.88)$ \\
\hline 2 & $\mathrm{CC}(5.54)$ & $\mathrm{CC}(5.45)$ & CR (5.38) & CR (5.42) & $\mathrm{DM}(5.4)$ & $\mathrm{DM}(5.77)$ & $\mathrm{CC}(5.73)$ & $\mathrm{DM}(5.75)$ \\
\hline 3 & $\mathrm{DM}(5.50)$ & $\mathrm{DM}(5.38)$ & $\operatorname{DM}(5.32)$ & $\operatorname{DM}(5.30)$ & CR (5.3) & CR (5.70) & CR (5.57) & CR (5.67) \\
\hline
\end{tabular}




\section{Conclusions and management insights}

\subsection{Main conclusions}

Different from previous studies, this paper discusses the contents and evolution of the composing factors of logistics enterprise competitiveness based on the enterprise type and life cycle dimensions. Five important conclusions are drawn as follows:

(1) The LEC is composed of corporate capabilities, corporate resources, and dynamic mechanism. The differences in the opportunities, challenges, and environment affect the LEC at different life cycle stages.

(2) In general, the competitiveness factors according to their importance level, descending, are corporate capabilities, corporate resources, and dynamic mechanism. The result shows that three capabilities (financial management capability, logistics risk control capability, and human resources management capability) and two resources (corporate human resource and culture resource) have the greatest influence on LEC but, in reality, have poor practical performance. Chinese logistics enterprises should improve these five factors in particular in the future.

(3) In view of the enterprise type, results show that the PLLC and SCMC emphasize strategic capability, the ULC gives more attention to entrepreneur capability, and the PRLC thinks highly of the logistics quality control capability. Customer resource is the most important resource for all types of logistics enterprises. Logistics network resource is the second most important resource for the PLLC and ULC, as well as the SCMC. Corporate financial resource ranks second in importance in the PRLC. All types of logistics enterprises regard the reaction mechanism as the most important dynamic mechanism.

(4) From the perspective of the enterprise life cycle, results show that strategic capability is very important at the initial stage. With the development of the enterprise, the importance of strategic capability begins to decrease, while logistics quality control and innovation capabilities increase. Customer resource is the key factor at the initial, growth, and regeneration stages, whereas logistics information technology resource becomes more important at the maturity stage. The reaction mechanism is crucial at all stages, especially at the regeneration stage.

(5) In consideration of the types of logistics enterprises and the enterprise life cycle, the importance of competitiveness factors is different from the general results shown in conclusion point (2). On the other hand, the PLLC and ULC regard corporate capabilities as the most important factor of the LEC, whereas the PRLC and the SCMC consider corporate resources as the primary factor. On the other hand, corporate capabilities are the primary factors, followed by dynamic mechanism and corporate resources, at the initial, growth, and regeneration stages; dynamic mechanism is the most important factor at the maturity stage.

\subsection{Management insights for managers}


From a managerial perspective, three implications are concluded based on the empirical results. First, to achieve and maintain competitiveness, the first task for managers is to identify the composing factors of LEC that are of greatest importance for the improvement of competitiveness. This study offers an effective framework for managers to select the most important factors in consideration of the type of enterprise and the enterprise life cycle.

Second, this study provides an illuminating insight of how Chinese logistics enterprises appraise competitiveness. This process is listed as follows:

(1) Identify the three categories of the composing factors of LEC: corporate capabilities, corporate resources, and dynamic mechanisms;

(2) Identify a common nature of capabilities underlying the three categories, similar to this study's investigation of the 14 corporate capabilities, eight corporate resources, and three dynamics mechanisms.

(3) Identify key composing factors that contribute to LEC and give the different weights for these factors.

(4) Evaluate the competitiveness of the logistics enterprise.

Managers might employ this process to examine whether the company could do more than its competitors using its various composing factors, and how its competitiveness can be identified and relative strengths exploited.

Third, according to the survey results, three capabilities (financial management capability, logistics risk control capability, and human resources management capability) and two resources (corporate human resource and corporate culture resource) have the strongest influence but poor performance in practice. Managers of Chinese logistics enterprises should pay more attention to these factors and develop a corresponding improvement plan according to the actual situation of their enterprises.

\subsection{Management insights for researchers}

From a research point of view, three insights are presented based on the research of this paper. First, this study improves the understanding of LEC, especially from the perspective of dynamic mechanism and the enterprise life cycle. It is beneficial for researches to conduct further research on LEC. Second, this study uses empirical investigation to validate and extend the theory of LEC. Visual illustrations by quadrant analysis diagrams for the importance rank and mean rank of composing factors of LEC are employed in this study, which could also be referenced for other similar empirical research. Third, the results are beneficial to researchers to create better evaluation index systems and find better evaluation methods of LEC.

There are still limitations in this research that can be studied further, however. First, as some internal relations exist between logistics business performance and logistics enterprises competitiveness, the composing factors and their evolution processes can be studied based on the 
different business performances. Second, this study does not analyze the correlation between the different factors. The Pearson correlation analysis and SEM can be applied in future research. In addition, the number of survey samples is relatively small; hence, future research can be established on a larger survey scale to obtain a more comprehensive understanding of LEC in China.

\section{References}

Alshawi, S. 2001. "Logistics in the internet age: towards a holistic information and process picture". Logistics Information Management 14 (4):235-241.

Ambastha, A., and Momaya, K. 2004. "Competitiveness of firms: review of theory, frameworks, and models". Singapore Management Review 26(1): 45-61.

Barney, J. 1991. "Firm resources and sustained competitive advantage". Journal of Management 17(1): 99-120.

Beinstock, C.C., Royne, M.B., Sherrell, D., and Stafford, T.F., 2008. "An expanded model of logistics service quality: incorporating logistics information technology". International Journal of Production Economics 113(1): 205-222

Bowman C., and Ambrosi V. 2003. "How the Resource-based and the Dynamic Capability Views of the Firm Inform Corporate-level Strategy ". British Journal of Management 14(4): 289-303.

Cantwell J. 2005. Innovation and competitiveness, in: J. Fagerberg, D. Mowery, R. Nelson (Eds.), The Oxford Handbook of Innovation, Oxford University Press, Oxford

Cavusgil, S.T., Calantone, R.J. and Zhao, Y.S. 2003. "Tacit knowledge transfer and firm innovation capability". Journal of Business \& Industrial Marketing 18(1):16-22.

Cameron, K.S. and Whetten, D.A. 1981. "Perceptions of organizational effectiveness over organizational life cycles". Administrative Science Quarterly 26(2): 525-544.

Canen, A.G. and Canen, A. 2004. "Multicultural competence and trust: a new road for logistics management?". Journal of Cross Cultural Management 11(3): 38-53.

Cetindama, D., and Kilitcioglu, H. 2013. "Measuring the competitiveness of a firm for an award system". Competitiveness Review: An International Business Journal 23(1): 7-22.

Chapman, R.L., Soosay, C., and Kandampully, J. 2003, "Innovation in logistics services and the new business model", International Journal of Physical Distribution \& Logistics Management 33(7): 630-50.

China Federation of Logistics \& Purchasing. 2010, “The top 50 logistics enterprises of China in 2010”, available at : http://finance.sina.com.cn/stock/t/20101105/13573509801.shtml (accessed 20 November 2013).

Chiu, H.N., 1995. "The integrated logistics management system: a frame- work and case study". International Journal of Physical Distribution \& Logistics Management 25 (6): 4-19.

Collis, D.J., and Montgomery, C.A. 1995, "Competing on resources: strategy in the 1990s". Harvard Business Review 73(4): 118-28.

Creazza, A., Dallari, F., and Melacini, A. 2010. "Evaluating logistics network configurations for a global supply chain”. Supply Chain Management: An International Journal15 (2):154 - 164.

Daugherty, P.J., Theodore, P.S., and Ellinger, A.E. 1998. "Leveraging logistics distribution capabilities: the impact of logistics service on market share". Journal of Business Logistics 19 (2): $35-51$. 
Ding, J.F. 2009, "Identifying key capabilities to determine core competence for ocean carrier-based logistics service providers", Journal of Innovative Computing Information and Control 51(9): 2627-2644.

Ding, N., Li, H.Q., and Wang, H.Q. 2013. "Analysis and prediction of logistics enterprise competitiveness by using a real GA-Based support vector machine." Proceedings of 2nd conference on logistics, informatics and service science (LISS 2012), VOL 1.

Eisenhardt, K. M., and J. A. Martin. 2000. "Dynamic Capabilities: What are They? ". Strategic Management Journal, 21(10/11): 1105-1121.

Esper, T.L., Fugate, B.S. and Davis-Sramek, B. 2007. "Logistics learning capability: sustaining the competitive advantage gained through logistics leverage". Journal of Business Logistics 28(2): 57-82.

Fan X.Q. 2009. "Fuzzy Theory and AHP Applied to Port Logistics Competitiveness Evaluation". 2009 International Conference on E-business and information system security: 337-341.

Fortune, A., and W., Mitchell. 2012. "Unpacking Firm Exit: Adaptation and Selection of Capabilities”. Strategy Management Journal 33(7): 794 - 819.

Fernandez, E., Montes, J.M. and Vazquez, C.J. 2000. "Typology and strategic analysis of intangible resource : a resource-based approach". Technovation 20(2): 81-92.

Ghemawat, P. 1986. "Sustainable advantage". Harvard Business Review 64(5): 53-58.

Gorynia M. 2004. "Competitiveness of polish firms and the European Union enlargement". Competitiveness Review: An International Business Journal incorporating. Journal of Global Competitiveness 14(1/2):1-11.

Gudmundsson S.V., and Nijhuis J. 2001. "Collaborative learning in logistics and transport: The application of 3WIM". International Journal of Physical Distribution \& Logistics Management 31(7/8):537 - 564

Gunasekaran, A., and Ngai, E.W.T. 2003. "The successful management of a small logistics company". International Journal of Physical Distribution \& Logistics Management 33(9): $825-42$.

Gunasekaran, A., and Ngai, E.W.T. 2004. "3PL: experiences from China resources logistics (Hong Kong)". International Journal of Logistics Systems and Management, 1(1): 81-97.

Haire, M. 1959. Biological Models and Empirical History of the Growth of Organizations: Modern Organizational Theory. John Wiley and Sons, New York, NY.

Han, S. and Huang, Y.H. 2008. "Study on identifying the life cycle stage of logistics enterprise's core competence", in Zhang, H., Zhao, R. and Zhang, H.J. (Eds), Logistics research and practice in China proceedings of 2008 international conference on logistics engineering and supply chain in Changsha, 2008, Orient Academic Forum, Sydney: 222-227.

Harding, F.E. 1998. "Logistics service provider quality: private measurement, evaluation, and improvement". Journal of Business Logistics 19(1): 103-21.

He, D.C. and Liu, W.H. 2011. The research of the modern logistics service system, Beijing, China Logistics Publishing House (in Chinese).

Houston, J.M., Farese D., and Du T.L. 1992. "Assessing competitiveness: a validation study of the Competitiveness Index". Personality and Individual Differences 13(10): 1153-1 156.

Jones, J.L., and Koehler, G.J., 2002. "Combinatorial auctions using rule-based bids". Decision Support Systems 34(1): 59-74. 
Kor, Y. Y., and Mesko, A. 2013. "Dynamic managerial capabilities: configuration and orchestration of Topexeutives' capabilities and the firm's dominant logic". Strategy Management Journal 34(2): 233-244.

Leontiades, M. 1980. Strategies for Diversification and Change, Little Brown, MA.

Lai, K.H. 2004, "Service capability and performance of logistics service providers", Transportation Research Part E: Logistics and Transportation Review 40(5): 385-399.

Lai, F., Li, D., Wang, Q., and Zhao, X., 2008. "The information technology capability of third-party logistics providers: a resource-based view and empirical evidence from China". Jorunal of Supply Chain Management 44 (3): 22-38.

Larson, P.D., and Gammelgaard, B. 2001. "The logistics triad: Survey and case study results". Transportation Journal 41(2/3):71-82.

Larson, P.D., and Kulchitsky, J.K., 1999. "Logistics improvement programs: the dynamics between people and performance". International Journal of Physical Distribution \& Logistics Management 29 (2): 88-102.

Li, W.D. 2008. "Combinational Evaluation on the Competitiveness of Logistics Enterprise". IEEE/SOLI'2008: Proceedings of 2008 IEEE international conference on service operations and logistics, and informatics: 2866-2871.

Liu C.L., and Lyons A.C. 2011. "An analysis of third-party logistics performance and service provision". Transportation Research Part E: Logistics and Transportation Review 47(4): 547-570.

Liu H.Y., and Hsu C.W. 2011. "Antecedents and consequences of corporate diversification: A dynamic capabilities perspective”. Management Decision 49(9): 1510-1534.

Liu, W.H., Liu, B.L., Chen, W.B., Wang, H.P., 2012. The composing elements and development path of China logistics enterprise competitiveness from a life cycle point of view. African Journal of Business Management Vol. 6(36), 9989-10002.

Liu, W.H., Liu, B.L., Wang, H.P., Chen, W.B., Jiao, Z.L., 2013. The Analysis of the Development Path of Local Logistics Company's Competitiveness based on the full life cycle. Wuhan University of Technology (Social Science Edition). 26(3):1-7 (In Chinese)

Liu, X.H. 2011. "Competitiveness of logistics service providers: a cross-national examination of management practices in China and the UK". International Journal of Logistics-Research and Applications 14(4):251-269.

Liu, X.H., Grant D.B., McKinnon A.C., and Feng Y.H. 2010. "An empirical examination of the contribution of capabilities to the competitiveness of logistics service providers A perspective from China". International Journal of Physical Distribution \& Logistics Management.40(10): 847-866.

Liu, Y.Q., Rong, J., and Yu X.Z. 2007a. "The research of dynamic capabilities theory and logistic enterprises' competitiveness". Proceedings of 2007 International Conference on Management Science \& Engineering (14th) Vols 1-3 : 687-691

Liu, Y.Q., Ye, L., and Guo, M. 2007b. "The Research of the Logistic Enterprises' Competitiveness: Based on the View of Dynamic Capabilities Theory and Competitive Advantage Theory". 2007 International conference on wireless communications, networking and mobile computing and computing VOLS 1-15: 4730-4735.

Lu, C.S. and Yang, C.C. 2010, "Logistics service capabilities and firm performance of international distribution center operators", Journal of Service Industries, 30(2): 281-298. 
Luo, Y. 2000. "Dynamic capability in international expansion". Journal of World Business 35(4): 355-378.

Mentzer, J.T., Foggin, J.H., and Golicic, S.L. 2000. "Collaboration: the enablers, impediments and benefits". Supply Chain Management Review 4 (4):52-58.

Mohamed, N., Gilbert, A. and Andrew, P. 2010. "Determining a logistics provider's flexibility capability". International Journal of Production Economics 127(1): 39-45.

$\mathrm{Mu}$ J.F. 2013. "Networking capability, new venture performance and entrepreneurial rent". Journal of Research in Marketing and Entrepreneurship 15(2):101-123.

Pannayides, P.M., and So,M. 2005. "Logistics service provider-client relationship". Transportation Research Part E: Logistics and Transportation Review, 41(3): 179-200.

Persson G., 1997. "Organization design strategies for business logistics". International Journal of Physical Distribution \& Logistics Management 27(5/6):282 - 291.

Porter, M.E. 1985. Competitive Advantage, The Free Press, New York, NY.

Prhalad, C.K. and Hamel, G. 1990. "The core competence of the corporation". Journal of Harvard Business Review 68(3): 79-91.

Ratten V. 2004. Learning and information dissemination in logistics alliances. Asia Pacific Journal of Marketing and Logistics 16(4):65 - 81.

Ralston, P.M. , Grawe, S. J., and Daugherty P. J. 2013. "Logistics salience impact on logistics capabilities and performance". The International Journal of Logistics Management 24(2): 136-152.

Richey, R.G., Daugherty, P.J. and Roath, A.S. 2007. "Firm technological readiness and complementarity: capabilities impacting logistics service competency and performance". Journal of Business Logistics 28(1):195-228.

Sandberg, E. and Abrahamsson, M. 2011. "Logistics capabilities for sustainable competitive advantage". Journal of Logistics Research and Applications 14(1): 61-75.

Shang, K.C., Wurman, P.B. 2005. "Logistics capability and performance in Taiwan's major manufacturing firms". Transportation Research Part E : Logistics and Transportation Review 41(3):217 - 234.

Shao, J.P., He, K.T., Dong, S.H., et al. 2008. "Evaluation model of regional logistics competence based on hierarchy and fuzzy decision". in Industrial informatics proceedings of the 6th IEEE international conference in Daejeon, Korea, 2008, IEEE, Pitscataway, N.J: 245-250.

Shmuel, E. and Noga, S. 2003. "Organizational learning mechanism and manager's perceived uncertainty". Human Relations, 56(10): 1233-1254.

Snyder, A.V. and Ebeling, H.J. 1992. "Targeting a company's real core competence". Journal of Business Strategy 13(6): 26-32.

Su, Z.F., Peng, J.S., and Xiao T. 2013. "Technological Capability, Marketing Capability, and Firm Performance in Turbulent Conditions". Management and Organization Review 9(1): 115-137

Tan, Y., Ma, S.H. and Gong, F.M. 2007. "Empirical study on impact of logistics operations capability on supply chain performance", in Wireless communications, networking and mobile computing proceedings of the 3rd international conference in Shanghai, China, 2007, IEEE, Pitscataway, N.J: 4760-4766.

Teece, D.J., Pisano, G. and Shuen, A. 1997. "Dynamic capabilities and strategic management". Strategic Management Journal 18(7): 509-533.

Thomas, O.T. and Harrington, D. 2003. "Boundaries and interfaces in management". Irish Journal 
of Management 24(1): 1-6.

Vulkan, N., and Jennings, N.R., 2000. "Efficient mechanisms for the supply of services in multi-agent environments”. Decision Support Systems 28(1/2):5-19.

Xiao, H.B. and Chen, J. 2008. "Research on concept and relevant factors of coal port logistics capability". in Material handling proceedings of the 6th international conference in Shanghai, China, 2008, China Machine Press, Beijing, China:156-160.

Wang, H.C. 2010. The Competitiveness of the Enterprises in the Dynamic Environment-the Research about the Development Path of the Enterprises' Competitiveness in the Dynamic View, Science Press, Beijing (in Chinese).

Wang, Q., Zantow, K., Lai, F., and Wang, X. 2006. "Strategic postures of third-party logistics providers in mainland China”. International Journal of Physical Distribution \& Logistics Management 36(10): 793-819.

Wang, C.L., and Ahmed, P.K. 2007. "Dynamic Capabilities: A Review and Research Agenda". International Journal of Management Reviews 9(1): 31-51.

Wong C.Y., and Karia N. 2010. "Explaining the competitive advantage of logistics service providers: A resource-based view approach". International Journal of Production Economics 128(1):51-67

Wurman, P.R., Walsh, W.E., and Wellman, M.P., 1998. "Flexible double auctions for electronic commerce: theory and implementation”. Decision Support Systems 24(1):17-27.

Yeung, J. 2006. "Orientation and operational priorities: an empirical study of third- -party logistics providers". International Journal of Physical Distribution and Logistics Management 36(3): 210-230.

Yeung, J.H.Y., Selen, W., Sum, C. and Huo, B. 2006. "Linking financial performance to strategic orientation and operational priorities: an empirical study of third-party logistics providers". International Journal of Physical Distribution \&Logistics Management 36(3): 210-30.

Yeo G.T., Roe M., and Dinwoodie J. 2008. "Evaluating the competitiveness of container ports in Korea and China". Transportation Research Part A: Policy and Practice 42(6): 910 - 921

Zahra, A. and Neubaum, D.O. 2003. "Environmental adversity and the entrepreneurial activities of new ventures". Journal of Developmental Entrepreneurship 3(2): 123-140.

Zhang L.R., Li Y.L., and Ma Y.J. 2010. "Evaluation of the Competitiveness of Logistics Enterprise Based on Niche". Electronic commerce and information engineering in China: Proceedings of the 2nd international symposium on electronic business and business and information system. 138-142.

Zhen, X. 2008. "The Method of Improve Enterprise Core Competitiveness -Based on the Technological Innovation and Take the Example of Logistics Enterprise". Proceedings of 2008 Northeast Asia logistics engineering and modern logistics industry development: 223-225

Zollo, M. and Winter, S.G. 2002. "Deliberate learning and the evolution of dynamic capabilities". Organization Science 13(3): 339-351.

Zoot, C. 2003. "Dynamic capabilities and the emergence of intra-industry differential firm performance: insight from a simulation study”. Strategic Management Journal 24(2): 97-125. 


\title{
Appendix 1: Survey Questionnaire
}

\section{Instructions}

\author{
Dear Sir/Madam,
}

In order to help managers understand which factor of LEC has a significant effect on the development of the China logistics enterprise, we would like to make a survey on it. The contents of the questionnaire include a survey on the importance of capabilities, resources, and dynamic mechanisms to LEC and a survey on the development stages of the company. The questionnaire consists of 4 pages with only quick-to-answer questions and takes around 20 minutes to fill out. There are 2 types of questions, one is questions with open ended answers, and the other is questions with perceptual scales which should be answered with seven-graded scales ranging between two extremes. We sincerely hope the question to be answered intuitively, since the questions are concerned with the perceived state of things. If you have any questions related to the survey, please call 0086-135 12833463 and Dr. Weihua Liu is always available on the phone during the office hour.

Thank you for your cooperation!

The research group of China logistics enterprise competitiveness

December 2010

\section{Survey on the basic information of Respondent}

The purpose of this part is to trace companies that have participated in the survey so that we can send the promised feedback later. We promise that all information of your companies and your answers to the questions in the survey are treated confidentially. If you are interested in participating in further research in the area, please enclose your business card in the answer envelope.

Questionnaire filled out by (Name)

1. Which position do you have at your company?

$\square$ Staff

$\square$ Department director

$\square$ Department Manager

$\square$ Senior executive

2. How many years have you been working in the logistics industry?

$\square$ Less than 2 years $\square 3$ to 5 years $\square 6$ to 7 years $\square$ More than 7 years

3. Other personal information:

(1) Your company name

(2) Your address

(3) Postal code 


\section{Part I - Basic company data}

1. Your company belongs to

The platform logistics company (such as ports enterprises, railway logistics enterprises, highway freight stations, air cargo stations, logistics park companies, etc, which provide platform-based services and station facilities)

The universal logistics company (such as transport enterprises, warehousing enterprises, express enterprises, Freight forwarding companies, comprehensive logistics companies, etc)

The professional logistics company (This type of company focuses on personalized and professional services suitable to a certain logistics company, such as the automotive, medical, appliance, etc.)

The supply chain management company (This type of company consists of companies such as the Hong Kong Li \& Fung Group. These companies can integrate and optimize the flow of logistics, information, and capital in the supply chain)

2. Number of employees

Less than 100

$101-500$

501-100

$1001-5000$

5001-10000

More than 10000

3. Annual sales turnover

Less than 10 million RMB

10 to 50 million RMB

50 to 100 million RMB

More than 100 Million RMB

Others

4. Your company is founded in (date).

Now your company is in the development stage of

Initial stage

Growth stage

Maturity stage

Regeneration stage (Second startup phase) 


\section{Part II - Logistics enterprise competitiveness}

Please give your rate according to the Likert scale.

1. How do you think of your company competitiveness Very poor Very good compared with other logistics companies? Indicate the extent of your evaluation (Please rate on a scale of $1-7,1$ is very poor, 7 is very good).

2. What do you think of the importance of the following capabilities on your company's competitiveness? Please rate on a scale of $1-7,1$ is equal to unimportant, 7 is equal to very important.

\begin{tabular}{|c|c|c|c|c|c|c|c|}
\hline \multirow[t]{2}{*}{ Capability category } & \multicolumn{7}{|c|}{$\begin{array}{c}\text { The effect of this capability } \\
\text { on the logistics enterprise } \\
\text { competitiveness }\end{array}$} \\
\hline & 1 & 2 & 3 & 4 & 5 & 6 & 7 \\
\hline \multicolumn{8}{|l|}{ Entrepreneur capability } \\
\hline \multicolumn{8}{|l|}{ Learning capability of logistics enterprise } \\
\hline \multicolumn{8}{|l|}{ Logistics solutions design capability } \\
\hline \multicolumn{8}{|l|}{ Logistics cost control capability } \\
\hline \multicolumn{8}{|l|}{ Logistics quality control capability } \\
\hline \multicolumn{8}{|l|}{ Logistics resources integrate capability } \\
\hline \multicolumn{8}{|l|}{ Logistics risk control capability } \\
\hline \multicolumn{8}{|l|}{ Logistics marketing capability } \\
\hline \multicolumn{8}{|l|}{$\begin{array}{l}\text { Strategic capability ( such as strategic foresight, } \\
\text { orientation ability and organization skills) }\end{array}$} \\
\hline \multicolumn{8}{|l|}{$\begin{array}{l}\text { Innovation capability (such as innovation consciousness, } \\
\text { innovation input and innovation organization) }\end{array}$} \\
\hline \multicolumn{8}{|l|}{ Departmental coordination capability } \\
\hline \multicolumn{8}{|l|}{$\begin{array}{l}\text { External interface coordination capability (Ability to } \\
\text { coordinate with customers, government, suppliers, etc.) }\end{array}$} \\
\hline \multicolumn{8}{|l|}{ Human resource management capability } \\
\hline $\begin{array}{l}\text { Financial management capability (Financial analysis, asset } \\
\text { value-added and raise capital ability) }\end{array}$ & & & & & & & \\
\hline
\end{tabular}

3、 What do you think of the importance of the following resources on your company's competitiveness? Please rate on a scale of $1-7,1$ is equal to unimportant, 7 is equal to very important. 


\begin{tabular}{|c|c|c|c|c|c|c|c|}
\hline \multirow[t]{2}{*}{ Resource category } & \multicolumn{7}{|c|}{$\begin{array}{c}\text { The importance of this resource } \\
\text { on the logistics enterprise } \\
\text { competitiveness }\end{array}$} \\
\hline & 1 & 2 & 3 & 4 & 5 & & 7 \\
\hline \multicolumn{8}{|c|}{ Logistics facilities and equipment resources } \\
\hline \multicolumn{8}{|c|}{ Logistics information technology resources } \\
\hline \multicolumn{8}{|c|}{ Logistics network resources } \\
\hline \multicolumn{8}{|c|}{ Logistics customer resources } \\
\hline \multicolumn{8}{|c|}{ Corporate financial resources } \\
\hline \multicolumn{8}{|c|}{ Corporate human resources } \\
\hline \multicolumn{8}{|c|}{ Knowledge and information resources } \\
\hline Corporate culture & & & & & & & \\
\hline
\end{tabular}

4. What do you think of the importance of the following dynamic matching mechanism on your company's competitiveness? Please rate on a scale of 1-7, 1 is equal to unimportant, 7 is equal to very important.

\begin{tabular}{|c|c|c|c|c|c|c|c|}
\hline \multirow[t]{2}{*}{ Three different kinds of mechanisms } & \multicolumn{7}{|c|}{$\begin{array}{l}\text { The importance of this matching } \\
\text { mechanism to the logistics enterprise } \\
\text { competitiveness }\end{array}$} \\
\hline & 1 & 2 & 3 & 4 & 5 & 6 & 7 \\
\hline $\begin{array}{c}\text { Motive mechanism (Such as the incentive constraints } \\
\text { mechanism, decision-making mechanism, etc.) }\end{array}$ & & & & & & & \\
\hline Learning mechanism (Such as training and learning, etc & & & & & & & \\
\hline $\begin{array}{l}\text { Reaction mechanism (Such as rapid response to } \\
\text { customers, competitors and other environment, etc.) }\end{array}$ & & & & & & & \\
\hline
\end{tabular}

5. In the development of logistics enterprise, the logistics enterprise competitiveness is composed of three kinds of competitiveness factors: enterprise resources, enterprise capabilities and the dynamics matching mechanism. What do you think of the importance of these three competitiveness factors on your company's competitiveness? Please rate on a scale of 1-7, 1 is equal to unimportant, 7 is equal to very important.

\begin{tabular}{|c|c|c|c|c|c|c|c|c|}
\hline \multirow{2}{*}{ competitiveness factors } & \multicolumn{6}{|c|}{$\begin{array}{c}\text { The importance of this } \\
\text { competitiveness factors to the } \\
\text { logistics enterprise competitiveness }\end{array}$} \\
\hline & 1 & 2 & 3 & 4 & 5 & 6 & 7 \\
\hline Corporate resources & & & & & & & \\
\hline Corporate capabilities & & & & & & & \\
\hline Dynamic matching mechanism & & & & & & & \\
\hline
\end{tabular}

